\title{
Efficacy of methyldopa versus nifedipine in mild and severe pregnancy induced hypertension
}

\section{Sopanrao Malharrao Togarikar*}

Department of Obstetrics and Gynecology, MNR Medical College and Hospital, Sangareddy, Telangana, India

Received: 03 August 2017

Revised: 05 August 2017

Accepted: 01 September 2017

\section{*Correspondence:}

Dr. Sopanrao Malharrao Togarikar,

E-mail: dr.togarikar@gmail.com

Copyright: (c) the author(s), publisher and licensee Medip Academy. This is an open-access article distributed under the terms of the Creative Commons Attribution Non-Commercial License, which permits unrestricted non-commercial use, distribution, and reproduction in any medium, provided the original work is properly cited.

\section{ABSTRACT}

Background: Hypertension and its associated disorders are major health concerns during pregnancy. Antihypertensive therapy prescribes, when blood pressure is $>140 / 90 \mathrm{~mm}$ of $\mathrm{Hg}$, to minimize elevated blood pressure. The present study aimed to assess the efficacy of nifedipine and methyldopa in the antihypertensive treatment of mild and severe pregnancy induced hypertension (PIH).

Methods: A total one hundred Patients attending antenatal clinic of the department between 26-37 weeks of gestation suffering from PIH were recruited. Participants were divided in to two groups i.e. group-I consists of 50 patients medicated with oral methyldopa and group-II consists of 50 patients treated with Nifedipine $10 \mathrm{mg}$.

Results: Methyldopa reduced systolic blood pressure (SBP) from $162 \pm 19.6$ to $140.3 \pm 10.01$ and diastolic blood pressure (DBP) from $99.6 \pm 8.8$ to $96.17 \pm 6.4$. Nifedipine reduced SBP from $99.6 \pm 8.8$ to $96.17 \pm 6.4$ and DBP from 99.2 \pm 7.4 to $93.45 \pm 12.3$. Response to methyldopa and nifedipine was almost similar in mild PIH but in severe PIH, $65.5 \%$ of patients required additional drug atenolol for adequate control of PIH.

Conclusions: Methyldopa and nifedipine are effective drugs for lowering blood pressure when given orally, Methyldopa was found to have a higher incidence of Intra uterine growth restriction while nifedipine was found to have an increased incidence of perinatal mortality.

Keywords: Diastolic blood pressure, Methyldopa, Nifedipine, Pregnancy induced hypertension, Proteinuria, Systolic blood pressure

\section{INTRODUCTION}

Pregnancy induced hypertension (PIH) also called gestational hypertension is the most happened complication during pregnancy which causes fetomaternal mortality and morbidity. ${ }^{1} \mathrm{PIH}$ is defined by systolic blood pressure $>140 \mathrm{mmHg}$ or diastolic blood pressure $>90 \mathrm{mmHg}$ for four hours or more. ${ }^{2}$ Globally, $5-20 \%$ pregnancies are suffering with $\mathrm{PIH}$, incidence varies from $2-8 \%$ in developed countries and almost $10 \%$ in developing countries. . $^{3,4}$
Antihypertensive therapy in PIH is to prevent complications due to hypertension while advancement of pregnancy thereby increases the foetal mortality. The commonly used antihypertensive drugs are methyldopa, nifedipine and Labetol. Since years, methyldopa is widely used in PIH treatment. It takes 12-24 hrs for adequate therapeutic response and large dose is required but it is helpful for long term control of blood pressure. Nifedipine is a non dihydropyridine calcium channel blocker with potent vasodilated property. It causes 
vasodilation in human pregnant uterine vessels as well foetal placental vessels. ${ }^{5,6}$

To ensure the above facts, the present study designed to assess the efficacy of calcium channel blocker nifedipine and methyldopa in the antihypertensive treatment of PIH.

\section{METHODS}

The present study was conducted in the Department of Obstetrics and Gynecology, MNR Medical College and Hospital, Sangareddy during July 2016 to May 2017. A total 100 Patients attending antenatal clinic of the department between 26 to 37 weeks of gestation suffering from PIH were recruited. For inclusion of cases, the following criteria was followed, mild PIH with BP between $140 / 90 \mathrm{~mm} \mathrm{Hg}$ to $160 / 110 \mathrm{~mm} \mathrm{Hg}$ with no significant proteinuria and severe PIH with BP >160/110 $\mathrm{mm} \mathrm{Hg}$ with significant proteinuria and patients with bronchial asthma, cardiovascular diseases, diabetes, multifetal gestation, antepartum haemorrhage were excluded from the study.

Detailed clinical history and demographic data was collected and participants were divided in to two groups i.e. group-I consists of 50 patients treated with oral methyldopa started as $250 \mathrm{mg}$, with maximum of $2 \mathrm{gm} /$ day in four divided doses and group-II consists of 50 patients treated with Nifedipine $10 \mathrm{mg}$, dose was increased up to $120 \mathrm{mg} / 1$ day.

Blood pressure was measured by mercury spigmomanometer. In all patients, the time of onset of hypertension was noted. Pedal oedema was detected by applying pressure on medial malleolus for 5 seconds. In suspected cases of IUGR, ultrasonography was done. Proteinuria was screened in all patients by using urine dipstick test.

Quantitative estimation of protein by Esbachs method was carried out if significant proteinuria was detected by urine dipstick method. Routine investigations like Haemoglobin, Urine examination, blood sugars, Platelet count, blood urea, Creatinine, uric acid were estimated in serum. After delivery, the gestational age of baby, birth weight, Apgar score at 1 minute and 5 minutes were noted. Foetal developing complications like jaundice, respiratory distress syndrome and hypoglycaemia were recorded.

\section{RESULTS}

A total one hundred patients fulfilling the study criteria were recruited from antenatal clinic of the department.

Out of which 50 patients were under group I and 50 under group II. Majority patients were between 21-30 years (Table 1). Based on parity all patients were equally distributed among both groups.
Majority cases were developed PIH between 32-35 weeks of gestation out of which $60 \%$ were in methyldopa group and $66 \%$ were in nifedipine group.

Table 1: Age wise distribution of PIH patients.

\begin{tabular}{|l|llll|}
\hline $\begin{array}{l}\text { Age } \\
\text { group } \\
\text { (in years) }\end{array}$ & No. & $\%$ & No. & $\%$ \\
\hline $15-20$ & 6 & 12 & - & - \\
\hline $21-30$ & 37 & 74 & 38 & 76 \\
\hline $31-40$ & 7 & 14 & 12 & 24 \\
\hline
\end{tabular}

Patients with more than 35 weeks of gestation developed $\mathrm{PIH}$ in $24 \%, 20 \%$ of methyldopa and nifedipine groups respectively (Figure 1).

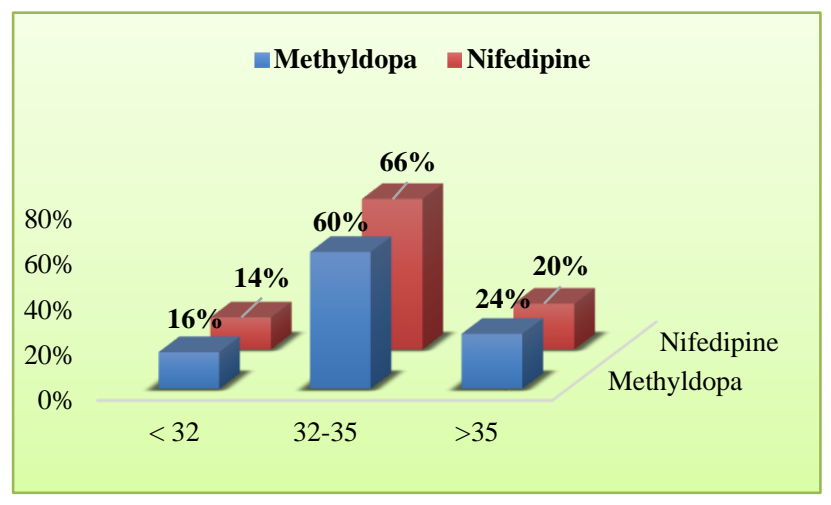

Figure 1: Distribution of cases according to gestational age.

In the view of severity of PIH, $68 \%$ of cases were with mild PIH and $32 \%$ of cases with severe PIH in both methyldopa and nifedipine groups cumulatively (Table 2).

Table 2: Distribution of cases according to severity of PIH.

\begin{tabular}{|c|c|c|c|c|}
\hline \multirow{2}{*}{ Category of patients } & \multicolumn{2}{|c|}{$\begin{array}{l}\text { Methyldopa } \\
(\mathbf{n}=\mathbf{5 0})\end{array}$} & \multicolumn{2}{|c|}{$\begin{array}{l}\text { Nifedipine } \\
(\mathbf{n}=\mathbf{5 0})\end{array}$} \\
\hline & No. & $\%$ & No. & $\%$ \\
\hline $\begin{array}{l}\text { Mild PIH } \\
(\mathrm{BP}<160 / 110 \mathrm{~mm} \mathrm{Hg})\end{array}$ & 42 & 84 & 26 & 52 \\
\hline $\begin{array}{l}\text { Severe PIH } \\
(\mathrm{BP}>160 / 110 \mathrm{~mm} \mathrm{Hg})\end{array}$ & 8 & 16 & 24 & 48 \\
\hline
\end{tabular}

All the cases of mild PIH in methyldopa and nifedipine group responded to single drug. Whereas, in severe PIH none of the patients responded to single drug therapy but gave response when the drug was combined with atenolol in all methyldopa group cases (Table 3).

There was no significant change in serum creatinine of both group and find significant change in serum uric acid in both groups (Table 4). 
Table 3: Drug response in cases of mild and severe PIH groups.

\begin{tabular}{|lllll|}
\hline Category of patients & Mild PIH $(\mathbf{n = 6 8 )}$ & & Severe PIH $(\mathbf{n = 3 2})$ & Nifedipine $(\mathbf{n = 2 4})$ \\
\hline Single Drug & Methyldopa $(\mathbf{n = 4 2})$ & Nifedipine $(\mathbf{n = 2 6})$ & Methyldopa $(\mathbf{n = 8})$ & 12 \\
\hline Combined with Atenolol & 42 & 26 & - & 12 \\
\hline
\end{tabular}

Table 4: Mean values of serum creatinine and uric acid concentration in PIH patients before and after treatment.

\begin{tabular}{|c|c|c|c|c|c|c|}
\hline \multirow[b]{2}{*}{$\begin{array}{l}\text { Treatment } \\
\text { groups }\end{array}$} & \multicolumn{3}{|c|}{ Serum creatinine (mg \%) } & \multicolumn{3}{|c|}{ Serum Uric Acid (mg \%) } \\
\hline & $\begin{array}{l}\text { Before } \\
\text { treatment }\end{array}$ & $\begin{array}{l}\text { After } \\
\text { treatment }\end{array}$ & p-value & $\begin{array}{l}\text { Before } \\
\text { treatment }\end{array}$ & $\begin{array}{l}\text { After } \\
\text { treatment }\end{array}$ & p-value \\
\hline Methyldopa & $80 \pm 26$ & $77 \pm 32$ & $<0.05$ & $6.26 \pm 3.98$ & $4.06 \pm 1.52$ & $<0.001$ \\
\hline Nifedipine & $84 \pm 20$ & $81 \pm 28$ & $>0.05$ & $5.75 \pm 1.42$ & $3.78 \pm 2.12$ & $<0.001$ \\
\hline
\end{tabular}

Improvement of oedema was observed in $92 \%$ of methyldopa and $88 \%$ in nifedipine groups. Whereas deterioration was observed in $8 \%$ in methyldopa and $12 \%$ in nifedipine groups. Proteinuria was improved in $90 \%$, $88 \%$ of both methyldopa and nifedipine groups respectively. No change in proteinuria was seen in $4 \%$, $8 \%$ cases in both groups respectively (Table 5).

Table 5: Effect of methyldopa and nifedipine on proteinuria and oedema.

\begin{tabular}{|c|c|c|c|c|}
\hline \multirow{2}{*}{ Category of patients } & \multicolumn{2}{|l|}{ Proteinuria } & \multicolumn{2}{|l|}{ Oedema } \\
\hline & Methyldopa & Nifedipine & Methyldopa & Nifedipine \\
\hline Improved & 45 & 44 & 46 & 44 \\
\hline Deteriorated & 3 & 2 & 4 & 6 \\
\hline No change & 2 & 4 & - & - \\
\hline
\end{tabular}

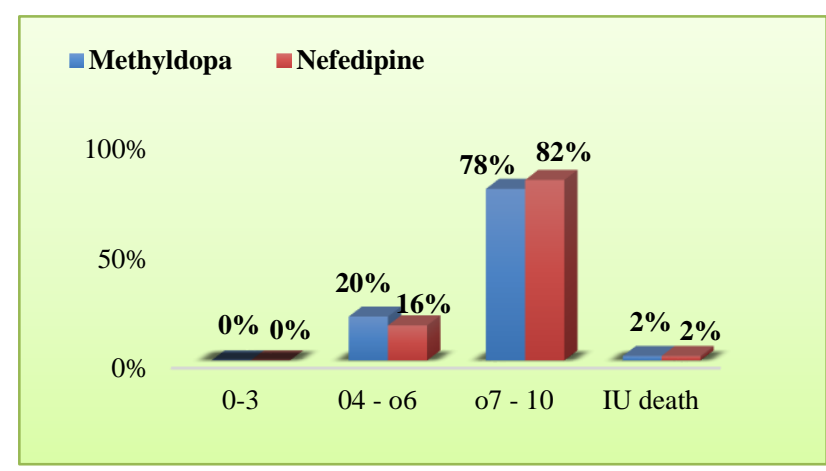

Figure 2: APGAR score of new born.
In mild PIH patients, majority pregnancies were terminated in methyldopa group $(83.3 \%)$ and nifedipine group $(88 \%)$ after 36 weeks of gestation. In severe PIH, nifedipine group $(54 \%)$ showed more terminations after 36 weeks of gestation. Majority cases had vaginal delivery in mild PIH cases in both medication groups but in severe PIH majority had delivery by LSCS in both groups. Majority of new borns had 7-10 Apgar score in both groups (Figure 2). The SBP reduced from $162 \pm 19.6$ to $140.3 \pm 10.01$ and DBP reduced from $99.6 \pm 8.8$ to $96.17 \pm 6.4$ in methyldopa group. While in nifedipine group, the SBP reduced from $99.6 \pm 8.8$ to $96.17 \pm 6.4$ and DBP reduced from $99.2 \pm 7.4$ to $93.45 \pm 12.3$ (Table 6).

Table 6: Mean changes in systolic blood pressure and diastolic blood pressure in both groups.

\begin{tabular}{|c|c|c|c|c|c|c|}
\hline \multirow[t]{2}{*}{ Medication } & \multicolumn{3}{|c|}{ Systolic blood pressure (SBP) } & \multicolumn{3}{|c|}{ Diastolic blood pressure (DBP) } \\
\hline & $\begin{array}{l}\text { Before treatment } \\
(\mathrm{mm} \mathrm{Hg})\end{array}$ & $\begin{array}{l}\text { After } \\
\text { treatment }\end{array}$ & p-value & $\begin{array}{l}\text { Before treatment } \\
(\mathrm{mm} \mathrm{Hg})\end{array}$ & $\begin{array}{l}\text { After } \\
\text { treatment }\end{array}$ & $\begin{array}{l}\text { p- } \\
\text { value }\end{array}$ \\
\hline Methyldopa & $162 \pm 19.6$ & $140.3 \pm 10.01$ & $<0.1$ & $99.6 \pm 8.8$ & $96.17 \pm 6.4$ & $<0.1$ \\
\hline Nifedipine & $169.4 \pm 27$ & $140.7 \pm 14.2$ & $<0.01$ & $99.2 \pm 7.4$ & $93.45 \pm 12.3$ & $<0.01$ \\
\hline
\end{tabular}




\section{DISCUSSION}

Blood pressure fluctuation and its maintenance during pregnancy is a challenging clinical problem to clinicians. The approach to evaluation and treatment differs substantially from non-pregnant women. Antihypertensive agents diminish the blood pressure and antihypertensive therapy in pregnancy induced hypertension is to prevent complications due to hypertension while advancement of pregnancy. The most commonly prescribed anti-hypertensive drugs are adrenergic receptor alpha-2 agonists such as Methyldopa, calcium channel blocker Nifedipine and Labetol. A study by Cvijiv $M$ et al stated methyldopa was most prescribed AHD in 285 of PIH patients, but study by Ray JG et al. revealed nifedipine $(47.7 \%)$ is most prescribed than methyldopa $(27.7 \%)$ cases. $^{7,8}$

In age distribution, majority patients were between 21-30 years in both methyldopa (74\%) and nifedipine groups (76\%) (Table 1). Age is an important factor to influence the incidence of hypertensive disorders in pregnancy. Primigravidae $<20$ years and others over 30 years have an increased chance of hypertension. ${ }^{9}$ In present study, majority cases were developed PIH between 32-35 weeks of gestation out of which $60 \%$ were in methyldopa group and $66 \%$ were in nifedipine group (Figure 1). These findings are correlating with the findings of Lardoux $\mathrm{H}$ et al. ${ }^{10,11}$

In the present study, use of anti-hypertensive drugs had reduced SBP and DBP significantly. After the use of methyldopa, the SBP reduced from $162 \pm 19.6$ to $140.3 \pm 10.01$ and DBP reduced from $99.6 \pm 8.8$ to $96.17 \pm 6.4$. While in nifedipine group, the SBP reduced from $99.6 \pm 8.8$ to $96.17 \pm 6.4$ and DBP reduced from $99.2 \pm 7.4$ to $93.45 \pm 12.3$ (Table 6). Sibai et al. showed significant reduction in the systolic $(\mathrm{p}<0.0001)$ and diastolic blood pressure $(\mathrm{p}<0.0001)$ with oral nifedipine in 200 women with pre-eclampsia between 26 and 36 weeks of gestation. ${ }^{12}$ Another study by Bharathi KN et al stated both methyldopa and nifedipine showed equal effect on reducing the blood pressure. ${ }^{13}$ Jayasudha et al, reported a significant reduction in systolic and diastolic $\mathrm{BP}$ after the use of methyl dopa with nifedipine. ${ }^{14}$

In the present study, improvement of oedema was observed in $92 \%$ of methyldopa and $88 \%$ in nifedipine groups. Whereas deterioration was observed in $8 \%$ in methyldopa and $12 \%$ in nifedipine groups (Table 5). Literature suggests that $80 \%$ of normal pregnancies commonly shows oedema. ${ }^{15}$ Proteinuria was improved in $90 \%$ and $88 \%$ of both methyldopa and nifedipine groups respectively (Table 5). Changes in proteinuria was almost similar in both groups, which is similar to the findings of Redman. ${ }^{16}$ Increase or onset of proteinuria is associated with increase in risks to the mother and fetus. ${ }^{17}$

In present study, serum creatinine and serum uric acid was significantly reduced before and after treatment in methyldopa and nifedipine groups (Table 4). Ismail et al. on preeclampsia patients found nifedipine decreased blood pressure and improved kidney function test without affecting fetomaternal blood supply. ${ }^{18}$

\section{CONCLUSION}

Antihypertensive drugs are preferred to reduce PIH, to protect and prolong pregnancy as long as possible. In the present study, response to methyldopa and nifedipine was almost similar in mild PIH but in severe PIH $65.5 \%$ of patients required additional drug atenolol for adequate control of PIH. Proteinuria was improved in $90 \%$ and $88 \%$ of both methyldopa and nifedipine groups respectively. Results of present study concludes that both methyldopa and nifedipine are effective drugs for lowering blood pressure when given orally Methyldopa was found to have a higher incidence of Intra uterine growth restriction while nifedipine was found to have an increased incidence of perinatal mortality.

Funding: No funding sources

Conflict of interest: None declared

Ethical approval: The study was approved by the Institutional Ethics Committee

\section{REFERENCES}

1. Kaunitz AM, Hughes JM, Grimes DA, Smith JC, Rochat RW, Kafrissen ME. Causes of maternal mortality in the United States. Obstet Gynecol. 1985 May 1;65(5):605-12.

2. Davey DA, MacGillivray I. The classification and definition of the hypertensive disorders of pregnancy. Am J Obstet Gynecol. 1988;158:892-8.

3. Gifford RW, August PA, Cunningham G. Report of the National High Blood Pressure Education Program Working Group on high blood pressure in pregnancy. Am J Obstet Gynecol. 2000;183:1-22.

4. Krauss T, Kuhn W, Lakoma C. Circulating endothelial adhesion molecules as diagnostic markers for the early identification of pregnant women at risk for development of preeclampsia. Am J Obstet Gynecol. 1997;177: 439-443.

5. Giannubilo SR, Bezzeccheri V, Cecchi S, Landi B, Battistoni GI. Nifedipine versus labetalol in the treatment of hypertensive disorders of pregnancy. Arch Gynecol Obstet. 2012;286:637-42.

6. Margaard S, Forman A, Anderson KE. Effect of Nifedipine on human placental artries. Gynaecol Obstet Investig. 1984;18:217-24.

7. Abalos E, Duley L, Steyn DW, Henderson-smart DJ. Antihypertensive drug therapy to mild to moderate hypertension during pregnancy. Cochrane Library. 2003;1.

8. Cvijic M, Horvat M, Jernejcic P, Verdenik I, Geršak $\mathrm{K}$. Analysis of the intake of drugs used in hypertensive disorders during pregnancy. Zdrav Vestn. 2010;79:412-8. 
9. Zibaeenazhad MJ, M Ghodsi P Arab, Gholzom N. the prevalence of hypertensive disorders of pregnancy in Shiraz, Southern Iran. Iranian Cardiovascular Res J. 2010;4:169-72.

10. Redman CWG, Gallery ED, Mitchell MD. Fall in BP in response to volume expansion in pregnancy associated hypertension (PE): Why does it occur? BMJ. 1984;2(2):177-82.

11. Lardoux H, Blazquez G, Leperlier E, Gérard J. Randomized, comparative study on the treatment of moderate arterial hypertension during pregnancy: methyldopa, acebutolol, labetalol. Arch Mal Coeur Vaiss. 1988;81:137-40.

12. Sibai BM, Barton JR, Sherif AKL, Sarinoglu C, Mercer BM. A randomized prospective comparison of nifedipine and bed rest versus bed rest alone in the management of preeclampsia remote from term. Am J Obstet Gynecol. 1992;167:879-84.

13. Bharathi KN, Prasad KVSRG, Jagannath P, Nalini KS. Comparison of Nifedipine with Methyldopa for Control of Blood Pressure in Mild to Moderate Pregnancy Induced Hypertension. J Clin Diagnos Res. 2010;4(3):2406-9.

14. Jayasutha J, Ismail AM, Senthamarai R. Evaluation on efficacy of Methyldopa monotherapy and combination therapy with Nifedipine in pregnancyinduced hypertension. Der Pharmacia Lettre. 2011;3:383-7.

15. Vidyadhar B, Giri P, Gavhane SP. A study to compare the efficacy of low dose magnesium sulphate (Dhaka) regime with Pritchard regime in eclampsia. Int J Biomed Adv Res. 2012;03(01):5358.

16. Redman CWG, Berlin IJ, Bonnar J, Ounsted MK. Fetal outcome in trial of antihypertensive treatment in pregnancy. Lancet. 1976 Oct 9;2(7989):753-6.

17. Seshadri L, Venkataraman I. Hypertension in Pregnancy Outcomes, Proteinuric vs. Nonproteinuric. J Reprod Med. 1997;42(2):88-90.

18. Ismail AAA, Medhat I, Tawfic TAS, Kholeif A. Int J Gynecol Obstet. 1993;1:39-43.

Cite this article as: Togarikar SM. Efficacy of methyldopa versus nifedipine in mild and severe pregnancy induced hypertension. Int J Reprod Contracept Obstet Gynecol 2017;6:4544-8. 